\title{
Butterfly Species Richness in Selected West Albertine Rift Forests
}

\author{
Patrice Kasangaki, ${ }^{1}$ Anne M. Akol, ${ }^{2}$ and Gilbert Isabirye Basuta ${ }^{2}$ \\ ${ }^{1}$ National Livestock Resources Research Institute (NaLIRRI), P.O. Box 96, Tororo, Uganda \\ ${ }^{2}$ Department of Biological Sciences, Makerere University, P.O. Box 7062, Kampala, Uganda \\ Correspondence should be addressed to Patrice Kasangaki, pkasangaki2005@yahoo.com
}

Received 20 March 2012; Revised 3 July 2012; Accepted 6 July 2012

Academic Editor: Alan Hodgson

Copyright (C) 2012 Patrice Kasangaki et al. This is an open access article distributed under the Creative Commons Attribution License, which permits unrestricted use, distribution, and reproduction in any medium, provided the original work is properly cited.

The butterfly species richness of 17 forests located in the western arm of the Albertine Rift in Uganda was compared using cluster analysis and principal components analysis (PCA) to assess similarities among the forests. The objective was to compare the butterfly species richness of the forests. A total of 630 butterfly species were collected in 5 main families. The different species fell into 7 ecological groupings with the closed forest group having the most species and the swamp/wetland group with the fewest number of species. Three clusters were obtained. The first cluster had forests characterized by relatively high altitude and low species richness despite the big area in the case of Rwenzori and being close to the supposed Pleistocene refugium. The second cluster had forests far away from the supposed refugium except Kisangi and moderate species richness with small areas, whereas the third cluster had those forests that were more disturbed, high species richness, and low altitudinal levels with big areas.

\section{Introduction}

Butterflies populate the entire land area of the earth except for the polar regions and the most arid deserts [1]. Each species occupies a definable geographical area, which is known as its area of distribution or, more simply, its range. Some species have ranges that cover very small areas while others have large ranges.

Butterflies also occur as distinct communities, which may be specific not only to geographical subregions but also to disparate ecological conditions $[2,3]$. Butterflies are known to respond to environmental changes and there have been considerable amounts of data collected on how particular species contend with alteration in land-use [3,4]. Because of their sensitivity to environmental conditions, butterflies have also been classified into ecological/functional groups that correspond more accurately to specific habitat conditions. The explicit environmental requirements of many species mean that they can have considerable value as indicators of community or habitat health [3] and may also play a valuable role in ecological monitoring [5].

In Uganda, about 1245 butterfly species have been recorded [6] from a variety of habitats and it is thus feasible to evaluate the butterfly fauna of the region as well as deriving reasonably accurate comparisons of sites and subsequently identify conservation requirements. The forests of the western arm of the Albertine Rift within Uganda are remnants of a once widespread forest ecosystem that has since become highly fragmented. Inspite of the fragmentation, the forests are still significant ecologically with respect to hydrological cycles and species conservation. The forests are under pressure from logging/deforestation and land-use change arising from increasing human populations and other development concerns. The impact of these pressures on these forests needs to be understood so that appropriate conservation requirements can be made.

The main objective of this study was to compare the butterfly species richness in selected forests of the West Albertine Rift within Uganda.

\section{Materials and Methods}

This study was based on data collected by the former Forest Department in Uganda, now National Forestry Authority (NFA) over a period of three years from January 1993 to December 1995 as part of a National Forestry Biodiversity in seventeen forests (Figure 1). 
Twelve fine-mesh cylindrical traps (approximately $70 \times$ $40 \mathrm{~cm}$ diameter) were set at a range of heights from 1$10 \mathrm{~m}$ above ground level for the duration of the survey. A variety of baits, namely, fermenting banana, dog feces, chicken offals, urine and locally distilled alcohol were used in the traps. Traps were checked regularly and representative specimens of each species collected. For those species not usually attracted to traps, sweep netting was carried out daily in a range of habitat types within the forests (Table 1). The average sampling efforts for each forest were measured in terms of man days. All the collected specimens were put in papers with their wing folded on the back and later identified.

\section{Data Analysis}

The butterfly species were assessed based on presence or absence of species for the different study forests.

(1) Cluster Analysis was used to determine the levels of similarities among the forests based on the presence or absence of butterfly species. This is a technique that sorts objects (such as sampling units) into groups or clusters based upon their overall resemblance to one another [7]. To establish the similarity among the forests, species presence $(=1)$ or absence $(=0)$ in the 17 forests was scored. These scores provided the basis for cluster analysis. To determine similarity of sites, total species richness $\times$ number of forests (17) array was used to calculate percent similarity indices [7]. The percent similarity ranged from near 0 (for a site pair highly dissimilar with respect to butterfly species) to near 1 (for a site pair very similar). An agglomerative clustering technique (weighted centroid) provided in the Multivariate Statistical Package [8] was used to produce a dendrogram containing all 17 forests. A minimum similarity index of 0.0 was used for defining clusters.

(2) Principal component analysis (PCA) was used to relate butterfly species distributions in the respective forests and to enhance the results of the cluster analysis. The data was centred, and two axes were extracted at the "low" $(1 E-4)$ level of accuracy. This is an ordination technique [9] which breaks down or partitions a resemblance matrix (variance-covariance or correlation) into a set of orthogonal (perpendicular) axes or PCA "components" [7]. The first few PCA components explain the largest percentage of variation in the data set [10] and ordinations of sampling units on these axes provide information about the ecological relationship between them.

\section{Results}

A total of 630 different butterfly species belonging to 5 families were recorded for all the 17 forests. All the five major families of butterflies were recorded in all the forests

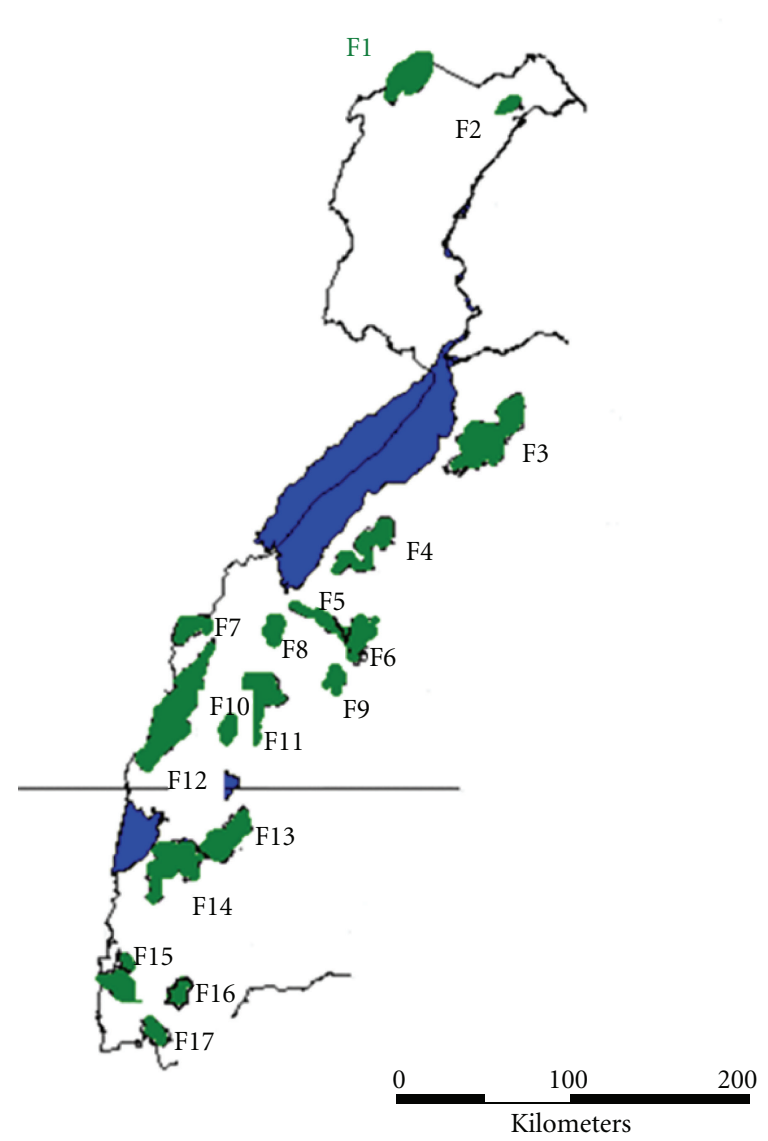

F1: Mt. Kei FR
F2: Era FR
F3: Budongo FR
F4: Bugoma FR
F5: Kagombe FR
F6: Kitechura FR
F7: Semliki NP
F8: Itwara FR
F9: Matiri FR

F10: Kisangi FR

F11: Kibale NP

F12: Mt. Rwenzori NP

F13: Kashyoha-Kitomi FR

F14: Kalinzu-Maramagambo FR

F15: Bwindi Impenetrable NP

F16: Mafuga FR

F17: Echuya FR

FIGURE 1: Location of the selected study forests in the Western Albertine Rift, Uganda.FR: Forest Reserve; NP: National Park.

except Mafuga in which only four were recorded. The family Nymphalidae had the highest species richness in all the forests followed by Lycaenidae and Hesperiidae. The number of species and subfamilies varied in all the forests. Papilionidae, a small family, had the lowest number of species recorded in a single forest with none in Mafuga (Figure 2).

The highest number of species was recorded in Semliki NP while the lowest number was in Mafuga FR (Table 2). Most forests had few open habitat species except Budongo, Era, and Mt. Kei Forest reserves (Table 2).

High species richness was recorded in forests within which the sampling effort was higher (Figure 3), suggesting that species richness in some forests could have been underestimated due to low sampling effort. For example, Semliki NP was sampled for more days than all the other forests. 
TABLE 1: Key characteristics of the study forests.

\begin{tabular}{|c|c|c|c|c|c|c|}
\hline Forest & $\begin{array}{l}\text { Size } \\
\left(\mathrm{km}^{2}\right)\end{array}$ & $\begin{array}{l}\text { Altitude } \\
\text { (masl) }\end{array}$ & $\begin{array}{c}\text { Location } \\
\text { (latitude/longitude) }\end{array}$ & When sampled & $\begin{array}{l}\text { Sampling } \\
\text { intensity } \\
\text { (man days) }\end{array}$ & $\begin{array}{c}\text { Average sampling } \\
\text { effort }(\text { man } \\
\left.\text { days } / \mathrm{km}^{2}\right)\end{array}$ \\
\hline Kalinzu-Maramagambo (Kal) & 854 & $915-1845$ & $\begin{array}{c}0^{\circ} 17^{\prime}-0^{\circ} 36^{\prime} \mathrm{N} \text { and } \\
29^{\circ} 47^{\prime}-30^{\circ} 10^{\prime} \mathrm{E}\end{array}$ & $\begin{array}{l}\text { November and December } \\
\text { 1993; August, October, and } \\
\text { December } 1994\end{array}$ & 44 & 0.08 \\
\hline Itwara (Itw) & 87 & $1220-1510$ & $\begin{array}{c}0^{\circ} 45^{\prime}-0^{\circ} 52^{\prime} \mathrm{N} \text { and } \\
30^{\circ} 25^{\prime}-30^{\circ} 32^{\prime} \mathrm{E}\end{array}$ & $\begin{array}{c}\text { July } 1992 \text { and January and } \\
\text { February } 1993\end{array}$ & 25 & 0.29 \\
\hline Bugoma (Bug) & 401 & $990-1295$ & $\begin{array}{c}1^{\circ} 07^{\prime}-1^{\circ} 25^{\prime} \mathrm{N} \text { and } \\
30^{\circ} 48^{\prime}-31^{\circ} 07^{\prime} \mathrm{E}\end{array}$ & $\begin{array}{l}\text { March to April } 1993 \text { and } \\
\text { July to August } 1994\end{array}$ & 59 & 0.15 \\
\hline Kisangi (Kis) & 54 & $914-1100$ & $\begin{array}{l}0^{\circ} 17^{\prime}-0^{\circ} 20^{\prime} \mathrm{N} \text { and } \\
30^{\circ} 14^{\prime}-30^{\circ} 18^{\prime} \mathrm{E}\end{array}$ & July 1993 & 6 & 0.11 \\
\hline Budongo (Bud) & 793 & $700-1270$ & $\begin{array}{c}1^{\circ} 37^{\prime}-2^{\circ} 03^{\prime} \mathrm{N} \text { and } \\
31^{\circ} 22^{\prime}-31^{\circ} 46^{\prime} \mathrm{E}\end{array}$ & $\begin{array}{c}\text { August to September } 1993 \\
\text { and September to October } \\
1994\end{array}$ & 53 & 0.06 \\
\hline Rwenzori (Rwe) & 996 & $1700-5109$ & $\begin{array}{c}0^{\circ} 06^{\prime}-0^{\circ} 46^{\prime} \mathrm{N} \text { and } \\
29^{\circ} 47^{\prime}-30^{\circ} 11^{\prime} \mathrm{E}\end{array}$ & $\begin{array}{c}\text { February, November, and } \\
\text { December } 1994\end{array}$ & 30 & 0.03 \\
\hline Echuya (Ech) & 34 & $2270-2570$ & $\begin{array}{l}1^{\circ} 14^{\prime}-1^{\circ} 21^{\prime} \mathrm{S} \text { and } \\
29^{\circ} 47^{\prime}-29^{\circ} 52^{\prime} \mathrm{E}\end{array}$ & $\begin{array}{c}\text { August 1993, July, } \\
\text { November, and December } \\
1994\end{array}$ & 8 & 0.24 \\
\hline Mafuga (Maf) & 34 & $2270-2570$ & $\begin{array}{l}1^{\circ} 00^{\prime}-1^{\circ} 05^{\prime} \mathrm{S} \text { and } \\
29^{\circ} 51^{\prime}-29^{\circ} 55^{\prime} \mathrm{E}\end{array}$ & $\begin{array}{c}\text { August 1993, July, } \\
\text { November, and December } \\
1994\end{array}$ & 6 & 0.16 \\
\hline Kagombe (Kag) & 113 & $1112-1372$ & $\begin{array}{c}0^{\circ} 34^{\prime}-0^{\circ} 54^{\prime} \mathrm{N} \text { and } \\
30^{\circ} 32^{\prime}-30^{\circ} 58^{\prime} \mathrm{E}\end{array}$ & April and May 1993 & 22 & 1.9 \\
\hline Matiri (Mat) & 54 & $1112-1372$ & $\begin{array}{c}0^{\circ} 34^{\prime}-0^{\circ} 54^{\prime} \mathrm{N} \text { and } \\
30^{\circ} 32^{\prime}-30^{\circ} 58^{\prime} \mathrm{E}\end{array}$ & April and May 1993 & 12 & 0.22 \\
\hline Kitechura (Kit) & 53 & $1189-1372$ & $\begin{array}{c}0^{\circ} 34^{\prime}-0^{\circ} 54^{\prime} \mathrm{N} \text { and } \\
30^{\circ} 32^{\prime}-30^{\circ} 58^{\prime} \mathrm{E}\end{array}$ & April and May 1993 & 14 & 0.26 \\
\hline Kasyoha-Kitomi (Kas) & 399 & $975-2136$ & $\begin{array}{l}0^{\circ} 05^{\prime}-0^{\circ} 25^{\prime} \mathrm{S} \text { and } \\
30^{\circ} 05^{\prime}-30^{\circ} 20^{\prime} \mathrm{E}\end{array}$ & $\begin{array}{l}\text { May and June } 1993 \text { and } \\
\text { September } 1994\end{array}$ & 45 & 0.12 \\
\hline Semliki (Sem) & 219 & $670-760$ & $\begin{array}{c}0^{\circ} 44^{\prime}-0^{\circ} 53^{\prime} \mathrm{N} \text { and } \\
29^{\circ} 57^{\prime}-30^{\circ} 11^{\prime} \mathrm{E}\end{array}$ & $\begin{array}{c}\text { January to April } 1993 \text { and } \\
\text { December } 1994\end{array}$ & 98 & 0.45 \\
\hline Kibale (Kib) & 679 & $1110-1590$ & $\begin{array}{l}0^{\circ} 12^{\prime}-0^{\circ} 40^{\prime} \mathrm{N} \text { and } \\
30^{\circ} 20^{\prime}-30^{\circ} 35^{\prime} \mathrm{E}\end{array}$ & $\begin{array}{c}\text { May and June } 1993 \text { and } \\
\text { September } 1994\end{array}$ & 35 & 0.06 \\
\hline Bwindi (Bwi) & 231 & $1190-2607$ & $\begin{array}{l}0^{\circ} 53^{\prime}-1^{\circ} 08^{\prime} \mathrm{S} \text { and } \\
29^{\circ} 35^{\prime}-29^{\circ} 50^{\prime} \mathrm{E}\end{array}$ & $\begin{array}{c}\text { February and September } \\
1994\end{array}$ & 24 & 0.07 \\
\hline Mt. Kei (Kei) & 384 & $915-1332$ & $\begin{array}{l}03^{\circ} 34^{\prime}-03^{\circ} 48^{\prime} \mathrm{N} \\
\text { and } \\
31^{\circ} 00^{\prime}-31^{\circ} 16^{\prime} \mathrm{E}\end{array}$ & $\begin{array}{l}\text { July and August 1993; June } \\
1994 \text { and September } 1995\end{array}$ & 53 & 0.14 \\
\hline Era (Era) & 74 & $850-1040$ & $\begin{array}{l}03^{\circ} 29^{\prime}-03^{\circ} 36^{\prime} \mathrm{N} \\
\text { and } \\
31^{\circ} 36^{\prime}-31^{\circ} 46^{\prime} \mathrm{E}\end{array}$ & $\begin{array}{l}\text { July and August 1993, April } \\
\text { and May 1994, and then } \\
\text { February } 1995\end{array}$ & 17 & 0.24 \\
\hline
\end{tabular}

There were 49 widely occurring butterfly species (recorded in at least 10 or more of the 17 forests) with Danaus chrysippus being the most common (found in 16 out of 17 forests), Gnophodes betsimena and Ypthima albida (recorded in 14 out of 17 forests), and Bicyclus jefferyi, Charaxes tiridates, and Neptidopsis ophione (recorded in 13 out of 17 forests). On the other hand, there were 394 rare butterfly species with members recorded in less than 5 forests each. 150 of these were recorded in only one forest each.

There were more closed forest species recorded in forests such as Kalinzu-Maramagambo, Bugoma, Budongo, Kasyoha-Kitomi, Semliki, and Kibale compared to the others with Semliki having the largest number of the closed forest species and Era, Mafuga and Echuya FRs having the least (Table 2). Edge species were also relatively abundant in all forests and so were the nonspecific habitat species. Swamp/wetland species were very few in all the forests as these were not their characteristic habitats.

Kibale and Bugoma forests had the highest percent similarity index of 63.4 (Figure 4), this was followed by Kasyoha-Kitomi and Kalinzu-Maramagambo and, Semliki and Budongo pairs both with 60.7, while other sites clustered at lower values. Using a minimum index of 0.00 for defining clusters (Figure 4, dashed line), the analysis produced three 
TABLE 2: Species richness in the 17 forests represented as ecological groupings.

\begin{tabular}{|c|c|c|c|c|c|c|c|c|c|}
\hline \multirow{2}{*}{ Number } & \multirow{2}{*}{ Forest } & \multicolumn{7}{|c|}{ Species richness per habitat } & \multirow{2}{*}{ Tota } \\
\hline & & $\mathrm{F}$ & $\mathrm{FH}$ & $\mathrm{FL}$ & $\mathrm{f}$ & $\mathrm{O}$ & $\mathrm{S}$ & Ns & \\
\hline 1 & Kalinzu-Maramagambo & 109 & 4 & 11 & 50 & 6 & 3 & 44 & 227 \\
\hline 2 & Itwara & 51 & 1 & 6 & 38 & 3 & 1 & 19 & 119 \\
\hline 3 & Bugoma & 141 & 2 & 13 & 59 & 9 & 1 & 53 & 278 \\
\hline 4 & Kisangi & 10 & 0 & 1 & 8 & 2 & 0 & 20 & 41 \\
\hline 5 & Budongo & 109 & 2 & 11 & 45 & 21 & 3 & 63 & 254 \\
\hline 6 & Rwenzori & 20 & 14 & 2 & 24 & 3 & 0 & 15 & 78 \\
\hline 7 & Echuya & 6 & 11 & 0 & 15 & 6 & 0 & 16 & 54 \\
\hline 8 & Mafuga & 4 & 7 & 0 & 8 & 3 & 2 & 8 & 32 \\
\hline 9 & Kagombe & 86 & 0 & 7 & 41 & 6 & 1 & 49 & 190 \\
\hline 10 & Matiri & 46 & 0 & 4 & 18 & 1 & 2 & 27 & 98 \\
\hline 11 & Kitechura & 45 & 0 & 5 & 31 & 2 & 2 & 29 & 114 \\
\hline 12 & Kasyoha-Kitomi & 119 & 2 & 11 & 47 & 7 & 1 & 48 & 235 \\
\hline 13 & Semliki & 166 & 2 & 17 & 49 & 12 & 1 & 62 & 309 \\
\hline 14 & Kibale & 105 & 1 & 10 & 55 & 3 & 3 & 43 & 220 \\
\hline 15 & Bwindi & 61 & 19 & 3 & 39 & 6 & 0 & 34 & 162 \\
\hline 16 & Mt. Kei & 12 & 0 & 2 & 19 & 30 & 3 & 60 & 126 \\
\hline 17 & Era & 3 & 0 & 1 & 2 & 19 & 0 & 31 & 56 \\
\hline
\end{tabular}

F: Closed forest, f: forest edge/woodland, FH: closed highland forest, O: open habitat, FL: closed lowland forest, S: swamp/wetland species, Ns: nonspecific habitat.

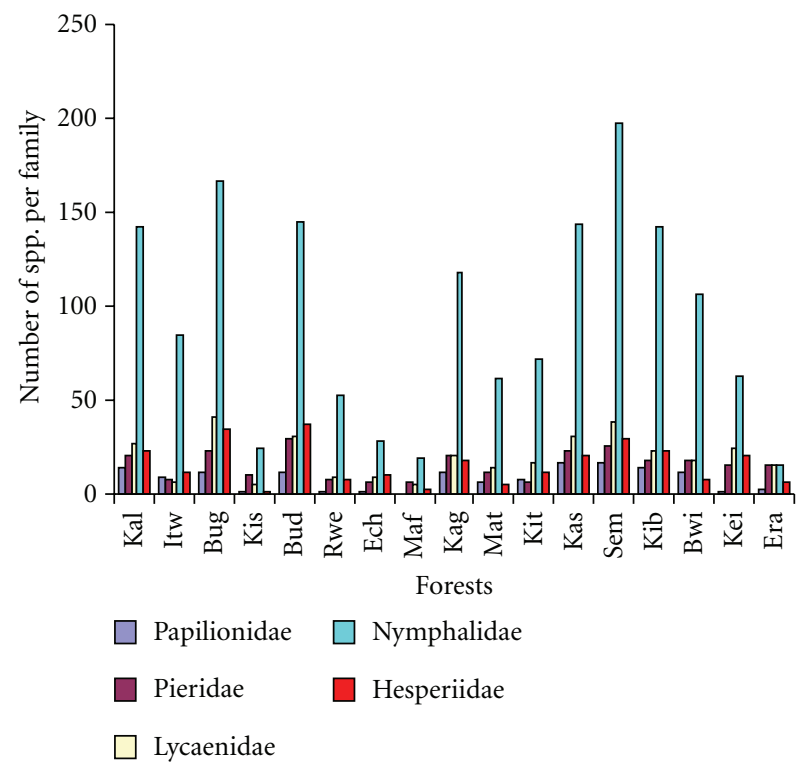

Figure 2: Number of butterfly species per family in the 17 West Albertine Rift Forests.Era: Era; Kei: Mt. Kei; Bwi: Bwindi; Kib: Kibale;Sem: Semliki; Kas: Kasyoha-Kitomi; Kit: Kitechura; Mat: Matiri;Kag: Kagombe; Maf: Mafuga;Ech: Echuya; Rwe: Rwenzori; Bud: Budongo; Kis: Kisangi;Bug: Bugoma; Itw: Itwara;Kal: KalinzuMaramagambo.

distinct groups of sites A, B, and C. Observed species richness recorded for the different forest clusters was 104 species in $\mathrm{A}$, 177 species in $\mathrm{B}$, and 561 species in $\mathrm{C}$.

Using principal components analysis, the first two principal components (PC1 and PC2) accounted for $35.2 \%$ of variance in the binary species data. A scatterplot of sites on PC1 and PC2 (Figure 5) suggested results similar to the cluster analysis shown in Figure 4. All forests with relatively high loadings on PC1 and having high scores, such as the Kallinzu-Maramagambo, Itwara, Bugoma, Kagombe, Matiri, Kasyoha-Kitomi, and Kibale are grouped in cluster $\mathrm{C}$ in the cluster analysis (Figure 4). On the other hand, forests with high loadings on PC2 and having high scores, such as Rwenzori, Echuya, and Mafuga, are members of cluster A (Figure 4).

\section{Discussion}

The observed variation in butterfly species richness among the forests (Figure 2) can be attributed to the sampling effort and the physical and environmental factors (forest size, altitude, number of plant species, forest disturbance, rainfall, temperature, and distance from the supposed Pleistocene refugium). This is supported by the works of Wood and Gillman [11], Cleary and Mooers [12], Posa and Sodhi [13] and Clark et al. [14] who separately studied species richness including that of butterflies in forests in relation to plant species richness and disturbance. They found some correlation between the number of butterfly species and forest area. Baz and Garcin-Boyero [15], on the other hand, found that there was no correlation between butterfly species richness and forest area. Our study shows that most of the bigger forests (cluster $\mathrm{C}$ forests) have higher species richness compared to those of clusters A and B except for Mt. Rwenzori which is a very high altitude forest.

While the similarity of Kasyoha-Kitomi and KalinzuMaramagambo is easy to explain (contiguous and therefore 


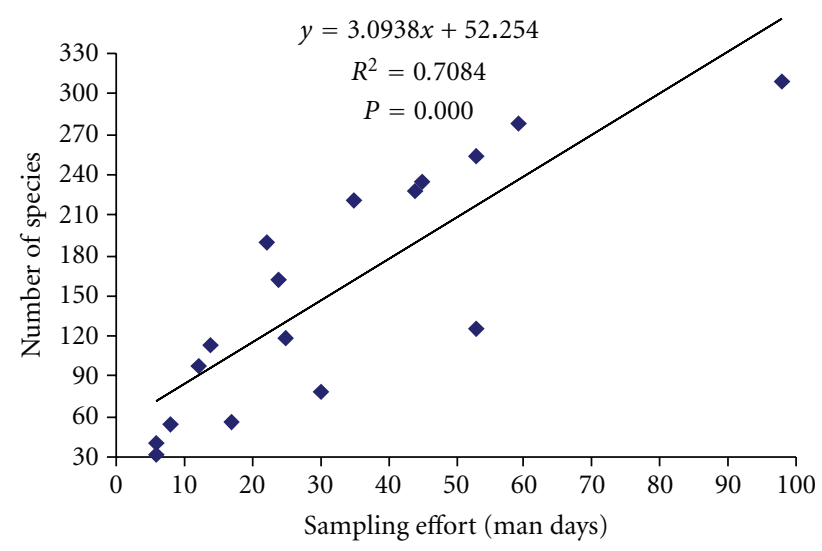

FIGURE 3: Sampling effort and number of species.

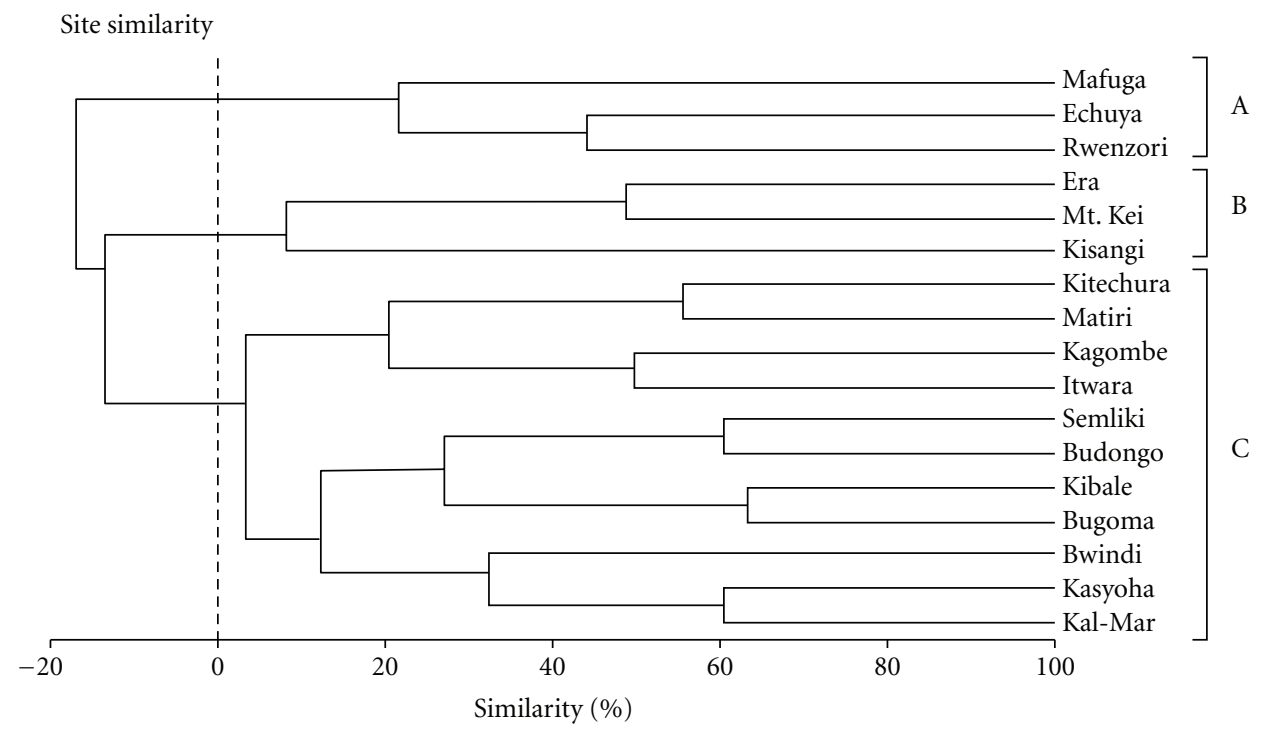

FIGURE 4: Clustering of the study forests based on the presence or absence of butterfly species.

are expected to have similar butterfly fauna), others are difficult to explain. It is possible that Bugoma and Kibale were contiguous in the far past but Semliki is very far from Budongo. Other factors such as isolation could have also influenced the butterfly species richness in the forests [12].

The butterfly species richness per forest indicated that forests (reserves) in the same cluster had comparable species richness (Figures 4 and 5). According to Diamond [16], reserves or habitat patches are considered to be "islands". Islands as ecological systems have such salient features as simple biotas and variability in isolation, shape, and size [17]. According to the theory of island biogeography [18], islands which are close to each other tend to have similar species compared to the isolated ones (this is also true for any other habitat). For example, Kitechura forest reserve which is a small forest $\left(53 \mathrm{~km}^{2}\right)$ and is contiguous with Kagombe forest reserve $\left(113 \mathrm{~km}^{2}\right)$ had a slightly higher butterfly species richness compared to Mt. Rwenzori NP forest reserve $\left(996 \mathrm{~km}^{2}\right)$ which is separated from other forests (Table 1 and Figure 2) and had low butterfly species richness (78 species). Kagombe which is contiguous with Kitechura and Matiri forest reserves had higher species richness than the other two. This may be attributed to the influence of a big forest nearby (Bugoma) which can also be explained by the MacArthur and Wilson's theory of island biogeography. In addition to the contiguity of forests as a variable accounting for the variation in species richness among the WARF's, the cluster analysis suggests that each of the three groups of forests may have similar physical and environmental attributes (Table 1).

Although Semliki NP appears as a small forest in Uganda, it is part of a very large forest in the eastern DRC, and this reason probably has been responsible for the high number of species in this forest. Also, Semliki NP was sampled more intensely than the other forests (an average sampling effort of 0.45 man days $/ \mathrm{km}^{2}$ ) as shown in Figure 3. Sampling effort showed a positive correlation with species richness. For example, only 162 butterfly species were obtained from Bwindi NP which was sampled for only 24 days during the survey compared to 181 species obtained from the same forest in 1991 by Omoding [19] who did intense sampling for about six months. On the other hand, Mafuga which is a young secondary forest and Echuya which is a bamboo forest 


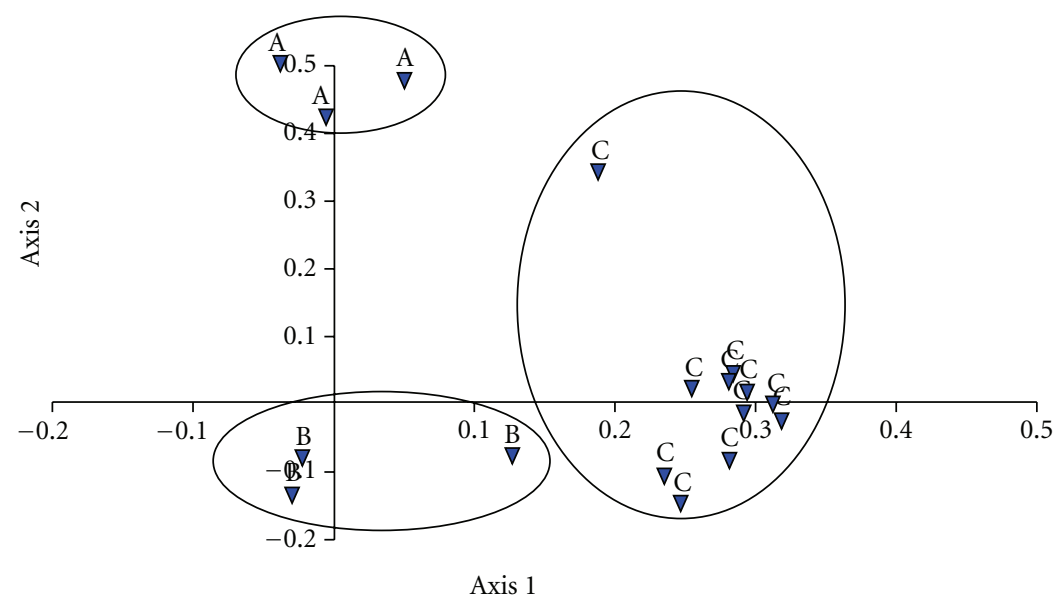

FIGURE 5: A scatter plot showing 17 forests plotted on principal component axes 1 and 2 (PC1 and PC2). Axes are linear combinations of butterfly species.

[20] all had lower species richness. These factors together with the high altitudes of the forests may have contributed to the small number of species obtained despite their close proximity to the supposed refugium. Mt. Rwenzori NP which is the largest forest among the study forests had a small number of species recorded. This could also be attributed to the small sampling effort (average of 0.03 man days $/ \mathrm{km}^{2}$ ) and then its location at a very high altitude and also the high rainfall associated with this area [2] which may not be favourable to butterflies.

The butterfly species which were most common to all the forests were from the family Nymphalidae. This is expected since the family constitutes a very diverse group [1] and occupies a wide range of habitats with about 440 species recorded in Uganda [4]. Species such as Danaus chrysippus and Gnophodes betsimena were recorded in almost all the 17 forests.

The butterfly fauna of the West Albertine Rift Forests was dominated by closed forest species (with Semliki recording as high as 166 species) [21]. This is in agreement with a study by Hill et al. [22] on tropical butterfly communities which found that these were diverse communities with many endemic species dependent on closed-canopy forests. This is because closed-canopy forests create microhabitats which are suitable for the butterflies. The present study also revealed that forest edge species were relatively abundant in all the forests in the West Albertine Rift. Waltert et al. [23] in a study on effects of land-use on bird species richness in Indonesia found that the forest edge could play an important role in the conservation of many species, but, although suitable for colonization, its potential to sustain populations over the long term is unknown. This is in agreement with this study which showed that forest edge species were relatively abundant in all the forests in the West Albertine Rift.

Wide range species (nonspecific habitat species) also had many representatives in all the forests. These are mainly generalist species that utilize a wide range of habitats in order to look for food and habitats for laying eggs. Kunte [24] observed that some butterfly species (e.g., Ypthima spp., family Nymphalidae) showed interesting trends with larval stage being grass feeders and adults feeding on a variety of fruits and nectar. These species are bound to occupy a wide range of habitats. Closed highland forest, closed lowland forest, swamp/wetland species, and open habitat species were generally few in all the forests implying that they are occupied by mainly specialist groups of butterflies.

\section{Conclusions}

There are more closed forest butterfly species in the WARFs than the swamp/wetland ecological group. This suggests that the WARF's have not changed very much from earlier times except for Era and Mt. Kei forest reserves which are very far from the supposed refugium and Echuya and Mafuga which are newly established forests.

\section{References}

[1] T. B. Larsen, The Butterflies of Kenya and Their Natural History, Oxford University Press, Oxford, UK, 1991.

[2] P. C. Howard, T. R. B. Davenport, and M. Baltzer, Eds., Forest Biodiversity Reports, vol. 1-33, Forest Department, Kampala, Uganda, 1996.

[3] T. R. B. Davenport, Endemic Butterflies of the Albertine RiftAn Annotated Checklist, The Wildlife Conservation Society, Mbeya, Tanzania, 2002.

[4] N. Carder and L. Tindimubona, Butterflies of Uganda: A Field Guide to Butterflies and Silk Moths from the Collection of the Uganda Society, Uganda Wildlife Society, 2002.

[5] G. C. Daily and P. R. Ehrlich, "Preservation of biodiversity in small rainforest patches: rapid evaluations using butterfly trapping," Biodiversity and Conservation, vol. 4, no. 1, pp. 3555, 1995.

[6] T. R. B. Davenport, The Butterflies of Uganda-An Annotated Checklist, Uganda Forest Department, Kampala, Uganda, 2003.

[7] J. A. Ludwig and J. F. Reynolds, Statistical Ecology: A Primer on Methods and Computing, John Wiley and Sons, New York, NY, USA, 1988. 
[8] W. I. Kovach, A Multivariate Statistical Package for Windows, Version 3.1, Kovach Computing Services, Pentraeth, Wales, UK, 1999.

[9] E. C. Pielou, Interpretation of Ecological Data, John Wiley and Sons, New York, NY, USA, 1984.

[10] H. G. Gauch, Multivariate Analyses in Community Ecology, Cambridge University Press, Cambridge, UK, 1982.

[11] B. Wood and M. P. Gillman, "The effects of disturbance on forest butterflies using two methods of sampling in Trinidad," Biodiversity and Conservation, vol. 7, no. 5, pp. 597-616, 1998.

[12] D. F. R. Cleary and A. Mooers, "Butterfly species richness and community composition in forests affected by ENSO-induced burning and habitat isolation in Borneo," Journal of Tropical Ecology, vol. 20, no. 4, pp. 359-367, 2004.

[13] M. R. C. Posa and N. S. Sodhi, "Effects of anthropogenic land use on forest birds and butterflies in Subic Bay, Philippines," Biological Conservation, vol. 129, no. 2, pp. 256-270, 2006.

[14] P. J. Clark, J. M. Reed, and F. S. Chew, "Effects of urbanization on butterfly species richness, guild structure, and rarity," Urban Ecosystems, vol. 10, no. 3, pp. 321-337, 2007.

[15] A. Baz and A. Garcia-Boyero, "The effects of forest fragmentation on butterfly communities in central Spain," Journal of Biogeography, vol. 22, no. 1, pp. 129-140, 1995.

[16] J. M. Diamond, "The island dilemma: lessons of modern biogeographic studies for the design of natural reserves," Biological Conservation, vol. 7, no. 2, pp. 129-146, 1975.

[17] J. Wu and J. L. Vankat, "Island biogeography: theory and applications," in Encyclopedia of Environmental Biology, W. A. Nierenberg, Ed., vol. 2, pp. 371-379, Academic Press, San Diego, Calif, USA, 1995.

[18] R. H. Macarthur and O. E. Wilson, The Theory of Island Biogeography, Princenton University Press, Princenton, NY, USA, 1967.

[19] J. Omoding, Status, distribution and ecology of butterflies in the impenetrable (Bwindi) forest, South-West Uganda [M.S. thesis], 1992.

[20] A. C. Hamilton, Environmental History of East Africa: A Study of the Quaternary, Academic Press, 1982.

[21] P. Kasangaki, A. M. Akol, and G. Isabirye Basuuta, "Butterfly species list for selected West Albertine Rift Forests," Dataset Papers in Biology, vol. 2013, Article ID 451461, 4 pages, 2013.

[22] J. K. Hill, K. C. Hamer, M. M. Dawood, J. Tangah, and V. K. Chey, "Rainfall but not selective logging affect changes in abundance of a tropical forest butterfly in Sabah, Borneo," Journal of Tropical Ecology, vol. 19, no. 1, pp. 35-42, 2003.

[23] M. Waltert, A. Mardiastuti, and M. Mühlenberg, "Effects of land use on bird species richness in Sulawesi, Indonesia," Conservation Biology, vol. 18, no. 5, pp. 1339-1346, 2004.

[24] K. J. Kunte, "Seasonal patterns in butterfly abundance and species diversity in four tropical habitats in northern Western Ghats," Life Research Foundation, 1997. 

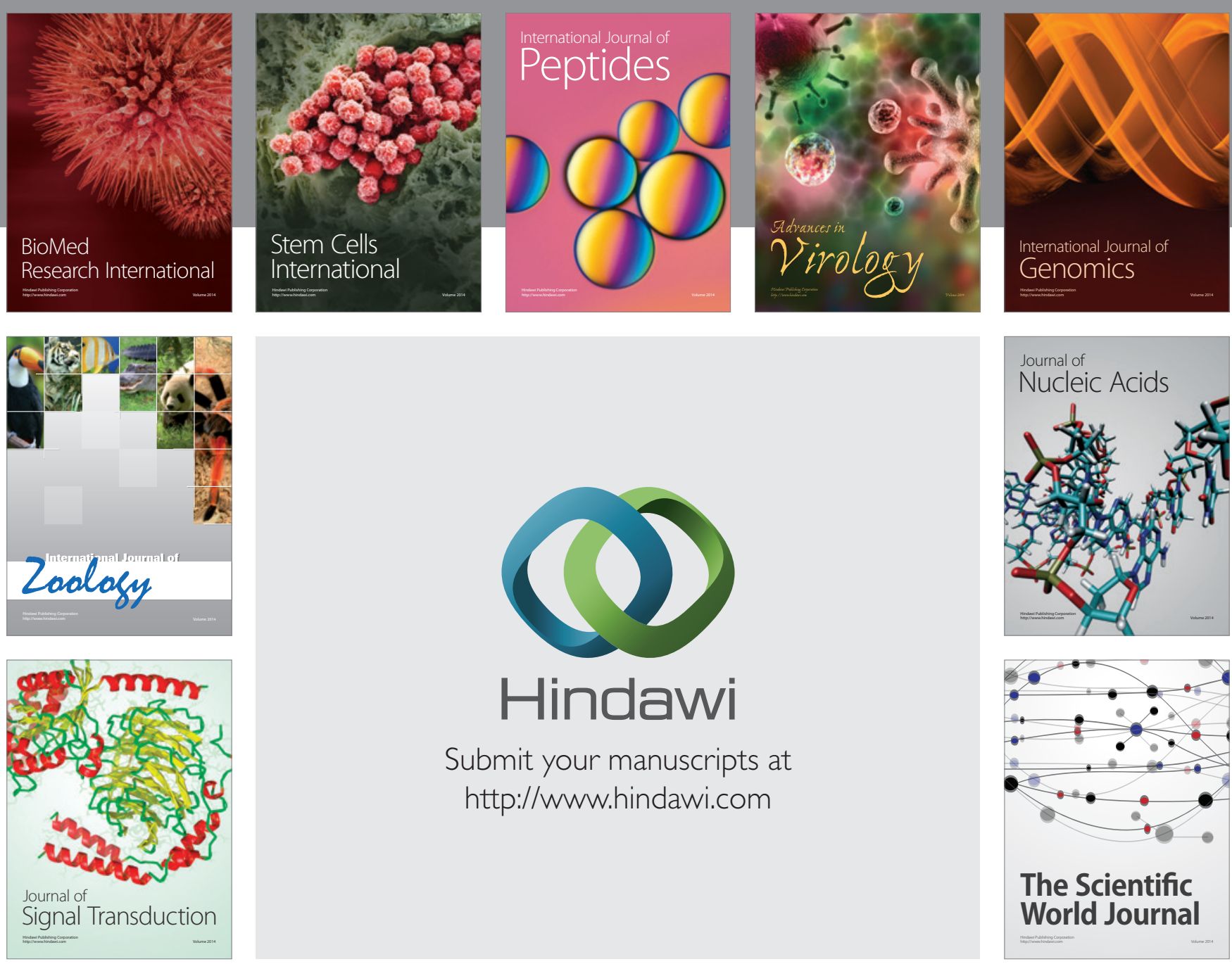

Submit your manuscripts at

http://www.hindawi.com
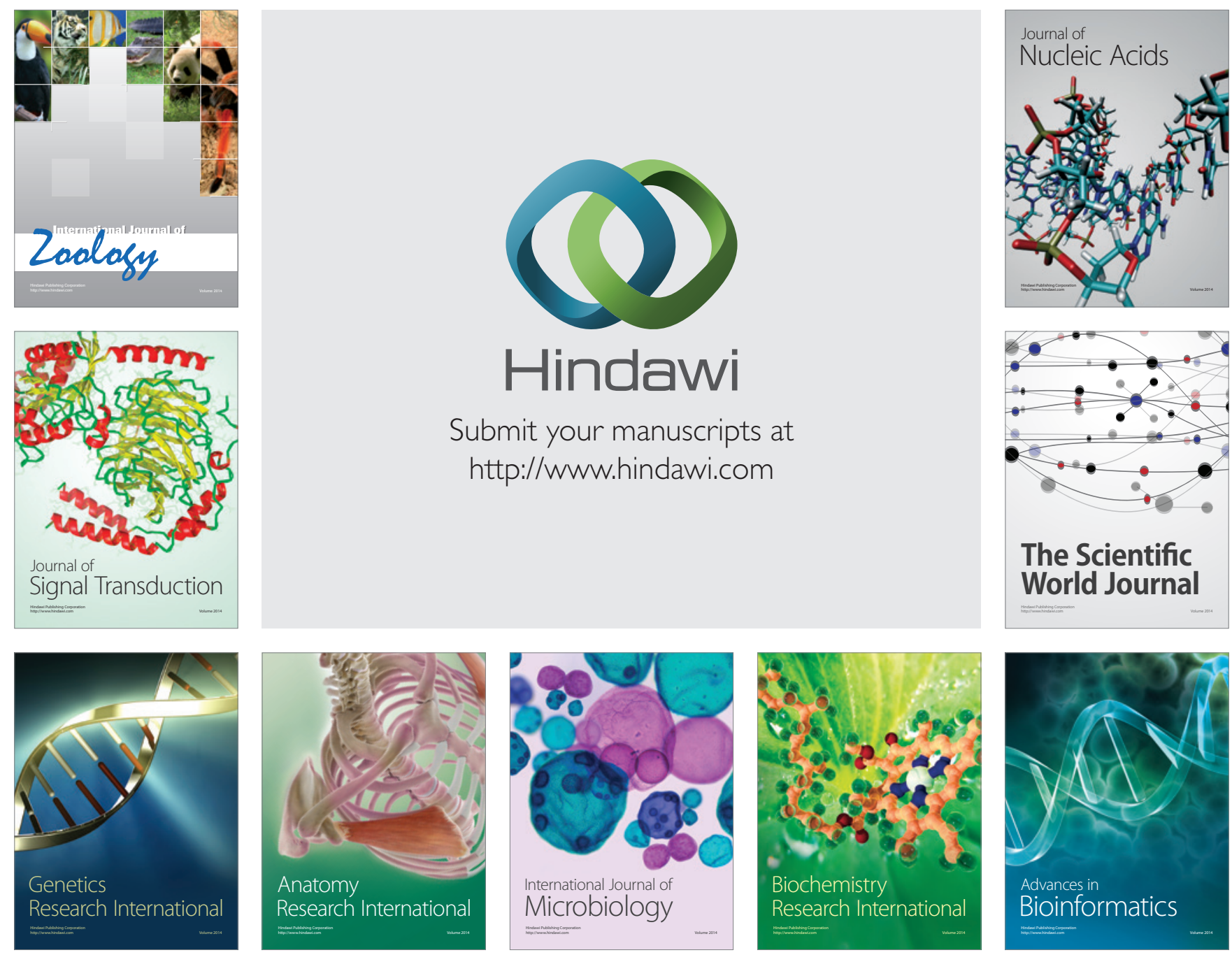

The Scientific World Journal
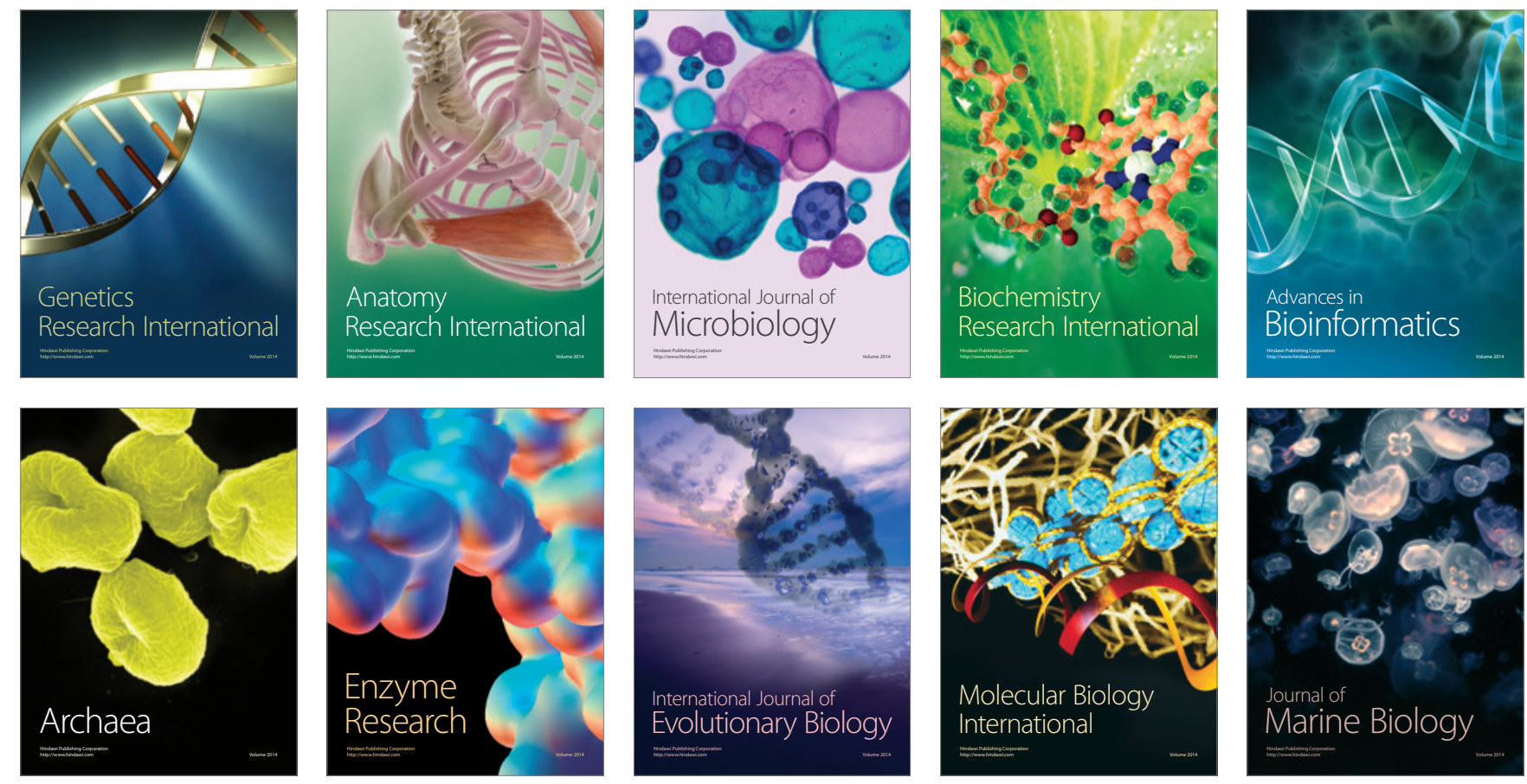